\title{
Study Data Tabulation Model Version
}

National Cancer Institute

\section{Source}

National Cancer Institute. Study Data Tabulation Model Version. NCI Thesaurus. Code C156605.

The version of the CDISC Study Data Tabulation Model that is being used in the study submission. 